\title{
Writing the World at the End of Empire
}

\author{
Brandon R. Byrd
}

Department of History, Vanderbilt University

${ }^{*}$ Corresponding author. E-mail: brandon.r.byrd@vanderbilt.edu

Priyamvada Gopal, Insurgent Empire: Anticolonial Resistance and British Dissent (London: Verso Books, 2019)

Adom Getachew, Worldmaking after Empire: The Rise and Fall of Self-Determination (Princeton: Princeton University Press, 2019)

The mythmaking began in 1808. Soon after the Parliament of the United Kingdom passed an Act for the Abolition of the Slave Trade, the English abolitionist Thomas Clarkson published the first history of the movement that had led to the ban on the trafficking of enslaved Africans within the British Empire. It was a testament to British benevolence. A tribute to Christian virtue. "The abolition of the Slave-trade took its rise, not from persons, who set up a cry for liberty when they were oppressors themselves, nor from persons who were led to it by ambition or a love of reputation among men, but where it was most desirable, namely, from the teachers of Christianity in those times," Clarkson proclaimed. ${ }^{1}$ In his telling, the inspiration for abolitionism had risen naturally from the same people who had dominated the transatlantic slave trade during the preceding century and would maintain colonial slavery for another three decades.

As historian Christopher Leslie Brown argues, the value of a narrative of abolitionism that celebrated British virtue and ignored enslaved resistance was crystal clear to Britons of the late Victorian and Edwardian eras. ${ }^{2}$ While colonial subjects in Great Britain's global empire and their allies in the metropole condemned the many manifestations of the violence and exploitation foundational to colonial rule, British intellectuals recast imperialism as the natural outgrowth of their antislavery heritage. They insisted that the British Empire had once undermined its own economic self-interest by acting so charitably on behalf of enslaved and trafficked Africans in 1808 and declared that it now delivered civilization to the world's backward races. They wrote in the service of nation and empire, "almost," as the Trinidadian scholar Eric Williams would note wryly, "as if Britain had introduced Negro slavery solely for the satisfaction of abolishing it." ${ }^{3}$

\footnotetext{
${ }^{1}$ Thomas Clarkson, The History of the Rise, Progress, and Accomplishment of the Abolition of the African Slave-Trade by the British Parliament, 2 vols. (London, 1808), 1: 262.

${ }^{2}$ Christopher Leslie Brown, Moral Capital: Foundations of British Abolitionism (Chapel Hill, 2012).

${ }^{3}$ Eric Williams, British Historians in the West Indies (London, 1966), 233. terms of the Creative Commons Attribution licence (https://creativecommons.org/licenses/by/4.0/), which permits unrestricted re-use, distribution, and reproduction in any medium, provided the original work is properly cited.
} 
By the mid-twentieth century, a teleology of slavery and empire was well established. Even as British politicians including Prime Minister Harold Macmillan recognized the inexorable tide of decolonization, they characterized that phenomenon as a mere repetition of "the processes which gave birth to the nation states of Europe." The British had stirred "national consciousness in peoples who have for centuries lived in dependence upon some other power." "It was colonial rule that allowed Africans, an inferior people capable of imitation but not innovation, to catch up to a much earlier stage of European political development. In this telling, decolonization was conservative rather than radical; a continuation, not a departure. It was the natural end of a natural process whose inevitable outcome-the postcolonial nation-state-was a European invention. ${ }^{5}$

Two recent books set the record straight.

In her most recent book, Insurgent Empire: Anticolonial Resistance and British Dissent (2019), Priyamvada Gopal, professor of postcolonial studies in the Faculty of English at the University of Cambridge, illuminates two intertwined aspects of British imperial history: colonial rebellion and metropolitan dissent. Building on the foundational work of black radical scholars such as Williams and C. L. R. James, in conversation with contemporaries including Antoinette Burton, Gopal refuses that narrative in which colonialism is characterized as a selfcorrecting device and emancipation and decolonization are represented as gifts given to enslaved and colonized people or even as the ends of slavery and empire. ${ }^{6}$ She recognizes subaltern resistance as constant and consequential-as central to self-liberation and the history of anticolonial politics and thought.

Part I of Insurgent Empire begins by reinterpreting the impact of what Gopal considers two exemplary crises of British empire: the Sepoy War of 1857 and the Morant Bay Rebellion. In the spring of 1857, the British press published lurid accounts of the uprising of Indian rebels, including peasants and native soldiers (sepoys) in the army of the British East India Company. Those reports not only emphasized the "barbarism" of the rebels but also presented a gruesome picture of the nature and scale of British repression. Many Britons soon read eyewitness accounts of British troops binding accused Indian insurgents to the mouths of cannons and then blowing them to bits. For some Britons, the violently suppressed rebellion "presented itself as a text that necessarily asked for a different kind of reading" (44). Focusing on the Chartist leader Ernest Jones, Gopal argues that some white Britons identified the insurgency as a model for a resurgent, democratic struggle of English workers, whose socioeconomic needs were denied by the same capitalist interests that demanded the violence of imperial rule. She offers an important reframing of the development of solidarity. For Gopal, the resistance

\footnotetext{
${ }^{4}$ Harold Macmillan, "The Wind of Change," African Yearbook of Rhetoric 2/3 (2011), 27-39. Gopal, Insurgent Empire, 442-3.

${ }^{5}$ On British responses to the demise of the British Empire after World War II see especially Stuart Ward, ed., British Culture and the End of Empire (Manchester, 2001).

${ }^{6}$ Antoinette Burton, The Trouble with Empire: Challenges to Modern British Imperialism (Oxford, 2015).
} 
of Indian insurgents was the catalyst for a praxis of solidarity in which "the political and the affective were mutually constitutive"-where "common human feeling" bound together a political community that recognized difference but identified and based its struggle on points of shared concern $(22,79)$.

As Gopal notes, the Sepoy War did not, could not, produce anything close to an anti-imperial consensus in Britain, but subsequent, similar colonial uprisings ensured that questions about the imperial project remained at the forefront of British public consciousness. From India, Gopal turns to Morant Bay, Jamaica, where in October 1865 hundreds of men and women of African descent marched into the town square, initiating a conflict with the local militia. She explores how Britons understood the uprising, which spread across the parish of St Thomas-in-the-East before John Edward Eyre, the governor of Jamaica, declared martial law and British troops burned down the houses of peasants, flogged and summarily shot hundreds of presumed rebels, and executed many others. The execution of George William Gordon, a colored member of Jamaica's House of Assembly, takes center stage. Gopal shows how the execution of Gordon on charges of conspiracy and the investigation of the Jamaica Royal Commission into the causes of the Morant Bay Rebellion created opportunities for Afro-Jamaicans to air their grievances. British newspapers printed the final letter from Gordon to his wife, in which he decried his undeserved death sentence and defended his recommendation that aggrieved Jamaican peasants "seek redress in a legitimate way" (96). The Jamaica Commission received letters from those peasants-from self-proclaimed "disobedient subjects," who assured their would-be rulers that "it must be life or death between us before we should live in such a miserable life" (102).

Britons such as the labor activist Frederic Harrison took note. A member of the Jamaica Committee, a group founded in opposition to Eyre's declaration of martial law in Jamaica, Harrison wrote in Martial Law: Six Letters to 'The Daily News', "We cannot make rules for negroes without baiting them like traps for Europeans." He asked, "Whose turn, be it colony or citizen, might not come next?" He insisted, "Every citizen in the empire, black or white, is periled by the sanction of outrage on any other" (122-3). Gopal argues convincingly that Harrison's dissent transcended the mere recognition that colonial subjects were also people and should not suffer the extreme violence of the colonial state. It is instead suggestive of a broader process in which the protests of Afro-Jamaicans helped radicalize British liberalism, encouraging among some British liberals more "racially inclusive and egalitarian conceptions of rights" (88).

In Chapters 3 and 4, Gopal gives special attention to the English writer Wilfrid Blunt while analyzing how travel accelerated the development of a culture of British anti-imperialism. In 1881, Blunt went to Egypt, tasked with convincing the popular Egyptian leader Colonel Ahmad Urabi of the legitimacy of European rule over Egypt. He returned to London in the spring of 1882 convinced of the very cause he was meant to suppress. As Gopal demonstrates, seeing the resistance to the beginning stages of the British occupation of Egypt sparked in Blunt a sympathy with the cause of Egyptian anticolonialism. He came to "see himself as an Egyptian nationalist" at the height of the age of British high imperialism (153). 
While Insurgent Empire is concerned with how crises at the colonial margins sparked dissent at the metropolitan center and, in doing so, closed the imagined distance between the two, the book offers tantalizing glimpses into the politics of the colonized themselves. It raises-even if its goal is not to answer-important questions about subaltern politics, which were as diverse as their origins. How do the political concerns of the mutineers of Chapter 1 compare to those of the Swadeshi movement, which, as covered in Chapter 4, emerged after the formation of the Indian National Congress and advocated for boycotts of British goods and the development of local industries in response to the British partition of Bengal? How do both compare and contrast with the politics of Jamaica's African and Afro-descendant populations? Gopal references sources in which Jamaican estate owners complained of tenants who refused to pay rent because "the Queen had given them the place when she gave them freedom" (106). She refers to rebels who had held mass meetings where they implored their peers to petition the queen for land, on which they were prepared to pay their share of taxes. These rich sources offer profound insights into the ideas about subjecthood and governance held by Jamaica's African and Afro-descendant people. They warrant further attention and additional readings as transcripts of rebellion and grassroots politics in which the colonial state appears as a site of belonging and an object of struggle.

The voices of a later generation of black and Asian political actors possessed of a more definitive anticolonial politics are more pronounced in Part II of Insurgent Empire, where Gopal adeptly reinterprets the anticolonial internationalism that flourished between World War I and World War II. In Chapters 5 and 6, Gopal focuses on Shapurji Saklatvala, a native of Bombay who moved to London and became an MP, first for the Labour Party, then as a Communist. He was only the third Indian politician seated in the House of Commons. In his own telling, Saklatvala was "one of the conquered and enslaved subject races" and the voice of the "British electors who sent me" to Parliament. He amplified growing, global critiques of empire as enslavement and promoted alliances between British labor and Indian nationalist movements, including as a member of the British section of the League against Imperialism. He embraced a "dual but intertwined representational responsibility," attempting as the House's unofficial "Member for India" to "forge a language of opposition to empire that would at once undo the pretences and prevarications of gradualist reformism and make clear that resistance to empire was in the interests of both the Indian and British working classes" (216).

Other "interpreters of insurgency" took similar actions (35). In a period of global anticolonial ferment, numerous activists and intellectuals from Africa, Asia, and the West Indies took up residence in London, where they pressed the anticolonial cause. Along with Saklatvala, these outspoken radicals included Claude McKay, George Padmore, and C. L. R. James. Taking advantage of democratic conventions that were offered in the metropole but routinely suppressed in the colonies, these men, along with equally influential female comrades like Amy Ashwood Garvey, who receive less attention in Insurgent Empire, introduced more incisive critiques of British nationalism and imperialism. In the years of the Second Italo-Ethiopian War and the Spanish Civil War, as World War II loomed on the 
horizon, they would, for instance, hold a mirror up to the hypocrisies of Great Britain, which practiced its own form of "colonial fascism."

Their words and actions had a demonstrable effect. As Gopal establishes in Chapters 7-9, black radicals forged formidable ties with British leftists. In turn, those British allies amplified the voices of black radicals, which clarified the intimate relationship between race and class. McKay published his work in the Workers' Dreadnought, the leftist paper edited by the British suffragist Sylvia Pankhurst. Padmore appeared alongside other pan-Africanists in Negro, the anthology edited by Nancy Cunard. These works were evidence of a robust praxis of solidarity, Gopal shows. They emerged from the process of reverse tutelage and seeded collaborations to come. Pankhurst and Cunard were among the British leftists who would join James, Padmore, and their comrades in the International African Friends of Abyssinia. The New Leader, the official newspaper of the Independent Labour Party (ILP), would amplify the anticolonial and anticapitalist politics of radicals such as Padmore and Jomo Kenyetta, the activist who would become Kenya's first head of state. The ILP's politics were radicalized by the same demands for national independence later aired at the Pan-African Congress held in Manchester, England in 1945. Just before that historic event, the ILP showed that it had arrived at a dissenting position on the question of Britain's imperial nationalism; in a resolution passed by its National Council, it pledged "to establish social justice in Britain and national liberation in the Empire" (372).

Insurgent Empire ends in the years after World War II, with an inexorable wave of decolonization precipitated by colonial rebellion but also supported by a small but influential cohort of British anti-imperialists. It brings the reader full circle, returning to two initial themes: the significance of travel from the metropole to the ostensible colonial margins and the "crises of conscience" caused by reports of counterinsurgency. In Chapter 10, Gopal focuses on the "Mau Mau rebellion," the uprising, primarily of Kikuyu people, that helped move Kenya towards independence from Great Britain. She shows through the case of Fenner Brockway how the uprising helped radicalize some British observers. As Gopal elucidates through a close reading of Brockway's travel memoir African Journeys, the MP and member of the ILP arrived in Kenya amid the anticolonial insurgency "convinced of the need for both moderation and gradualism." He witnessed the visceral forms of violence characteristic of colonial rule. He returned to London sympathetic to the oppositional use of violence in the cause of freedom, at the start of "his transformation ... into a full-time British anticolonialist" (406). In 1954, Brockway became the founding president of the Movement for Colonial Freedom (MCF). His reports on British atrocities in Kenya earned him the nickname "Member for Africa" and helped transform the MCF into a "mass movement against imperialism" in Brockway's somewhat hyperbolic telling, that would, in fact, enjoy the support of almost a hundred MPs and about twenty British trade unions (423).

Spanning the century from the Sepoy mutiny to the Mau Mau rebellion, Insurgent Empire succeeds in showing that Britain's colonized subjects not only struck for their own rights and freedoms but, through their resistance, also reshaped British intellectual and political culture. Reading a robust "archive of dissidence, opposition and criticism in relation to the British Empire," Gopal's work reverses the traditional pathways of imperial and intellectual history, in which ideas 
radiate from the metropole outwards, from Europe's colleges and cathedrals to the "non-Western" world (454). It disrupts the most essential and essentialized categories of the post-Enlightenment world, including the very notions of "Western" and "European." As Gopal reveals, the values and ideals often acclaimed as the invention and inheritance of people who imagined themselves as white truly emerge fully realized among the colonized and oppressed. The language of colonial insurgents is baked into modern discourses of liberalism, liberty, and justice. Current understandings of freedom and equality owe as much to the peasants in Morant Bay as they do to the philosophers of the Enlightenment. In writing these truths, Gopal reminds us of what today's apologists for empire would have us forget: that, as Frantz Fanon argued, it was the task of the enslaved, the colonized, and their descendants to create the new man-to "invent a man in full"-whom Europe was wholly incapable of "achieving" or even imagining.

In Worldmaking after Empire: The Rise and Fall of Self-Determination, Adom Getachew, the Neubauer Family Assistant Professor of Political Science and the College at the University of Chicago, reexamines the political imaginations of anticolonialists who endeavored to create new nations, finding, like Gopal, a rich intellectual history obscured by imperial myths. As Getachew notes, politicians and academics in twentieth-century Europe and North America depicted empire as alien rule and argued that its stunning collapse was a credit to Western culture. Echoing Harold Macmillan, the Harvard political scientist Rupert Emerson would, for example, argue in 1960 that "through global conquest the dominant Western powers worked to reshape the world in their own image and thus roused against themselves the forces of nationalism which are both the bitterest enemies of imperialism and, perversely, its finest fruit" (quoted at 16). ${ }^{8}$ This narrative blunted the radical challenge that anticolonial nationalism posed to the project of European imperialism, Getachew argues. It continues to obscure how anticolonial nationalists understood decolonization-not as "a seamless and inevitable transition from empire to nation" but as a "radical rupture ... that required a wholesale transformation of the colonized and a reconstitution of the international order" (17).

Getachew disrupts the traditional account of decolonization as an expansion of an existing state system by recasting anticolonial nationalism as worldmaking. Focusing on the political thought of anticolonial leaders in the anglophone Caribbean and Africa following World War II, Getachew argues that anticolonial nationalism "propelled a rethinking of state sovereignty, inspired a far-reaching reconstitution of the postwar international order, and grounded the twentieth century's most ambitious vision of global redistribution" (2-3). She finds it to be internationalist, not parochial, and far more innovative and imaginative than imitative.

Getachew elaborates on this pivotal intervention in Chapter 1. Reading recent and foundational works in political theory and international relations alongside

\footnotetext{
${ }^{7}$ Frantz Fanon, The Wretched of the Earth, trans. Richard Philcox (New York, 2004), 236.

${ }^{8}$ Rupert Emerson, From Empire to Nation: the Rise to Self-Assertion of Asian and African Peoples (Cambridge, 1960), 16-17.
} 
the writings of anticolonialists such as Kwame Nkrumah and W. E. B. Du Bois, Getachew reconceptualizes colonization as the experience of unequal integration into international society rather than simply a problem of alien rule. The creation of an international society as "an internally differentiated space" inclusive of sovereign states, quasi-sovereign states, colonies, and other non-sovereign polities emerged with the expansion of Europe (18). This society took shape in the application of the "law of nations" to Indigenous people found to be in defiance of that law's prescriptions and the signing of treaties and alliances between Europeans and non-Christians in the Americas and Asia. It solidified in the nineteenth century's nation-state formation, imperial expansion, and racial science, coalescing into a racialized international hierarchy or what $\mathrm{Du}$ Bois would call the "global color line." Accordingly, Getachew argues that anticolonial thinkers such as Nkrumah thought that decolonization needed to respond to the flexibility and malleability of empire and "overcome the background conditions of unequal integration and international hierarchy that facilitated domination" (22-3). They understood that the conditions of empire could survive outside direct political control and therefore postcolonial freedom would require independent states and international institutions that would help secure the conditions of nondomination.

A formative moment in the development of this anti-imperial critique came in the period between World War I and World War II. Challenging the intransigent, conservative narrative of decolonization, which holds that anticolonial nationalists not only imitated the nation-state form but also adopted the language of selfdetermination invented by Woodrow Wilson, Getachew recasts the so-called Wilsonian moment as a "counterrevolutionary moment" in which Wilson and the South African statesman Jan Smuts stifled the revolutionary potential of Bolshevik theories of self-determination, proposed a racially differentiated principle of self-determination, and preserved a racialized international hierarchy in the League of Nations (40). She considers black responses to the deployment of selfdetermination in the interests of empire, as demonstrated in the US occupation of Haiti (1915-34), the unequal treatment of Ethiopia and Liberia in the League of Nations, and the Italian invasion of Ethiopia in 1935 (40). For intellectuals such as Du Bois, C. L. R. James, and George Padmore, the imperial invasion of Ethiopia especially dramatized the dire condition of what Getachew calls "burdened membership" - "a form of inclusion in international society where responsibilities and obligations were onerous and rights and entitlements limited and conditional" (54). It galvanized a pan-Africanist politics that was rooted in "a critique of colonialism as a dual structure of slavery and racial hierarchy" and seeded the ground for subsequent projects of "national independence coupled with anticolonial worldmaking that sought to secure nondomination within the international order" $(67,70)$.

In this light, anticolonial nationalists reinvented rather than appropriated the idea of self-determination. Moving from the end of World War I to the aftermath of World War II, picking up where Insurgent Empire leaves off, Worldmaking after

\footnotetext{
${ }^{9}$ W. E. B. Du Bois, "To the Nations of the World" (1900), W. E. B. Du Bois Papers, MS 312, Special Collections and University Archives, University of Massachusetts Amherst Libraries, at http://credo. library.umass.edu/view/full/mums312-b004-i321.
} 
Empire challenges a romanticized account of the birth of the United Nations (UN) and the foundations of the post-World War II world. In this account, the UN's founding documents serve as the basis for a post-World War II world characterized by the realization of an international order of independent and equal states born in the Treaty of Westphalia and now enshrined in a universal right to selfdetermination. The conservatism of the UN and the intellectual work of anticolonial nationalists are obscured. As Getachew demonstrates, anticolonial nationalists such as Nnamdi Azikiwe recognized that the UN, in its founding moment, threatened to extend the hierarchies institutionalized by the League of Nations and subordinate the principle of self-determination to the practical work of securing international peace, as defined by the nation-states of the North Atlantic. They outlined an alternative, egalitarian vision of the postwar world at the Fifth Pan-African Congress. Rather than a natural outgrowth of the UN Charter or Western culture more generally, the passage of the historic Resolution 1514 by the UN General Assembly in 1960 reflected the success of the anti-imperial and anticolonial politics of pan-Africanism. That resolution, the Declaration on the Granting of Independence to Colonial Countries and Peoples, which declared that "the subjection of peoples to alien subjugation, domination and exploitation constitutes a denial of fundamental human rights," represented not a Wilsonian understanding of self-determination but a critique of empire as enslavement and a vision of selfdetermination as the legal basis of nondomination. ${ }^{10}$

While the reinterpretation of the "anticolonial reinvention of selfdetermination" offered in Worldmaking after Empire thus suggests that 1960 was a moment of revolutionary potential, it leaves visible the many contradictions inherent in the institutionalization of anticolonial struggle. Getachew is forthright about the parameters of a book whose principle subjects are lettered male elites and national leaders such as Du Bois, Azikiwe, and Nkrumah. She acknowledges that there were limits to anticolonial self-determination, made evident in the Congo crisis and what historian Ryan Irwin has called the quintessential postcolonial problem: "the relationship of borders to people" (102). ${ }^{11}$ These points are ripe for further exploration; the relationship between the worldmaking aspirations of anticolonial intellectuals and subaltern visions of autonomy and sovereignty forged in everyday struggle and expressed in spiritual and secular terms should be explored even more. Although it is accurate, as Getachew argues, that the nation-state "has come to represent a political form incapable of realizing the ideals of a democratic, egalitarian, and anti-imperial future," it is also true that for many ordinary people excluded from formal political power, the state, even the ostensibly postcolonial state, was an imposition that never had democratic or egalitarian potential (1). Their struggles, revealed in decolonial histories such as Jean Casmir's The Haitians, prioritized institutions and social relations crafted on the local level against capitalist modes of labor over the relationships among

\footnotetext{
10“Declaration on the Granting of Independence to Colonial Countries and Peoples," New York, 14 Dec. 1960, United Nations, Audiovisual Library of International Law, Historic Archives, Decolonization, https:// legal.un.org/avl/ha/dicc/dicc.html.

${ }^{11}$ Ryan M. Irwin, "Sovereignty in the Congo Crisis," in Leslie James and Elisabeth Leake, eds., Decolonization and the Cold War: Negotiating Independence (New York, 2015), 205.++Note 11. Please supply full page span. House style is to give full spans as well as numbers of pages of specific interest.++
} 
states and the illusory promise of citizenship. ${ }^{12}$ They reflected worldmaking ambitions, which, in many ways, further illuminate the intentions as well as the contradictions and limitations of Getachew's protagonists.

Still, by giving careful attention to the nuanced political visions of her elite protagonists, Getachew calls needed attention to the often overlooked contingencies of the era of decolonization. In what Getachew calls the first phase of anticolonial worldmaking, a generation of university-educated intellectuals and political leaders including Nkrumah and Eric Williams tried to create regional federations in Africa and the West Indies. Their projects-the Union of African States and the West Indian Federation, respectively-were short-lived but illustrative. While "Black Atlantic federalists" had different ideas about the forms that federalism should take, they imagined federation as a means of economic development and a solution to the "postcolonial predicament" - what Getachew defines as "the disjuncture between formal independence and de facto dependence" (108). In Africa and the Caribbean, federalism emerged from a trenchant critique of the limits of postcolonial sovereignty and political imaginaries that did not see the nation-state as the inevitable end of empire. Its collapse into forms of regionalism that sought to protect the state's political sovereignty and territorial integrity while often eliding its internal political and ethnic differences reintroduced the stark realities of the postcolonial predicament.

In Chapter 5, Getachew analyzes the New International Economic Order (NIEO), the bold response to the demise of federalism initiated by a subsequent generation of anticolonial worldmakers. During the 1960s and 1970s, prices for the primary goods exported by many postcolonial states dropped precipitously. Postcolonial states relied increasingly on foreign aid and debt. In what Getachew describes as the second and most ambitious project of anticolonial worldmaking, Jamaican prime minister Michael Manley and Tanzanian president Julius Nyerere tried to resolve the problem of dependence and redress the inequitable terms of trade between the so-called developing nations and their developed counterparts. The NIEO-“a welfare world" in Getachew's analysis-was their solution (144). Founded in 1964 and chartered by the UN General Assembly a decade later, the NIEO was the mechanism through which postcolonial political leaders envisioned economic and political equality among states, implemented socialist ideals, and tried to overcome the problem of postcolonial dependence. It affirmed that each state had sovereignty over its natural resources and the right to the regulation and even expropriation of private corporations. It called for a transformation of world trade through a global system of preferences that would give developing nations access to the markets of the developed nations. The political visions that informed the NIEO were certainly not without their limitations-as Getachew notes, the "formulation of postcolonial states as the workers and farmers of the world ... evaded the question of the workers and farmers within postcolonial states" (167). Still, the story of its rise and fall demonstrates the international orientation of anticolonial nationalism and serves as a reminder of the different paths that the history of decolonization might have taken.

\footnotetext{
${ }^{12}$ Jean Casimir, The Haitians: A Decolonial History, trans. Laurent Dubois (Chapel Hill, 2020).
} 
In the epilogue of Worldmaking after Empire, readers travel the road that connects the colonial past to our neocolonial present. By the final decades of the twentieth century, European and North American intellectuals and politicians looked upon decolonization with increasing skepticism and outright hostility. Western critics argued that the real and imagined failures of postcolonial states delegitimized the definition of self-determination as a human right. The dream of the NIEO receded, replaced by the nightmare of structural adjustment. Amid a global debt crisis that afflicted developing nations and the attendant ascension of a neoliberal world order of liberalization and privatization that has harmed workers worldwide, the United States led a diminution of some international institutions such as the UN; the consolidation of others, namely the World Bank and the International Monetary Fund; and an entrenchment of racialized hierarchy in the international order. A current era of unrestrained US empire reached its apogee after the events of 11 September 2001, "as the threat of terrorism, a resurgent nationalism, and an assertive executive branch justified preemptive war; encouraged the arrogation of international conventions on war, torture, and detention; and strengthen unrepresentative and exclusionary institutions like the [UN] Security Council to advance American interests" (179).

A reactionary "case for colonialism" now buttresses what Kehinde Andrews calls "the new age of empire" in which the financial crisis of 2008 intensified the forces of neoliberalism and the United States remains an epicenter but certainly not the sole pursuant of global empire. ${ }^{13}$ In Insurgent Empire, Gopal notes that "British public life and political discourse have been mired in a tenacious colonial mythology in which Britain-followed by the remainder of the geopolitical West-is the wellspring of ideas of freedom, either 'bestowing' it on slaves and colonial subjects or 'teaching' them how to go about obtaining it" (447). The same can be said of Britain's fellow liberal democracies throughout the Western world. Amid a global resurgence of anticolonial and antiracist protest and organizing and the mainstreaming of marginalized histories through initiatives like the 1619 Project, neocolonialists defend the "benefits" of the British Empire on the British Broadcasting Corporation, pledge loyalty to the monarchy, and plead the "case for colonialism" in periodicals and academic publications. French politicians insist that racism is an impossibility in a republic that does not legally recognize race. In the United States, federal and state politicians have passed bills prohibiting the teaching of critical race theory and promoting "patriotic education." One bill celebrates the date when Texas became a slaveholding republic. In these various iterations of colonial and white-supremacist propaganda posing as history, the West is never the enslaver but the philanthropist, the abolitionist not the colonizer. Above all, it is benevolent, so any criticism of it is revisionist, meaning biased and retrospective.

Amid this reactionary backlash, Insurgent Empire and Worldmaking after Empire offer timely lessons from past revolutionary struggles. As Gopal notes, a full accounting of the past reveals a rich history of British dissent from which contemporary anticolonial, antiracist, and peace organizations can look to with pride. The history of "the colonized-in-struggle" holds particular lessons for Britain's

\footnotetext{
${ }^{13}$ Kehinde Andrews, The New Age of Empire: How Racism and Colonialism Still Rule the World (New York, 2021).
} 
African, Caribbean, and Asian populations but it should also give "heart and hope to those who look towards a more fully decolonized future for both Britain and the postcolonial world" (455). While that future world must still be imagined and forged through struggle, Getachew reminds readers that this work of worldmaking can be done, should be done, just as it has been tried before. Throughout the past century, anticolonial nationalists revised their political strategies and reenvisioned the postcolonial world following grave disappointments and frustrating moments of closure, when the world's imperial powers proved most stubborn and the structures of colonialism demonstrated their dynamism. Their example suggests that the current demise of the liberal international order may be less crisis than opportunity to make the world anew.

Ultimately, Insurgent Empire and Worldmaking after Empire are essential additions to a growing body of decolonial scholarship. ${ }^{14}$ Both dismantle intransigent myths about the rise and fall of Europe's direct imperial rule and demand a rethinking of the political solidarities and strategies created by insurgents, activists, and scholars who envisioned a postcolonial world. They attend to the same questions as their protagonists, asking a new generation of anticolonial thinkers to dream and scheme, to know that what is does not have to be, to invent that "man in full" and realize first through the imagination a truly emancipatory process of decolonization.

\footnotetext{
${ }^{14}$ On this body of scholarship see the reading list on decolonization and anti-racism published by Verso: "Decolonization and Anti-racism," Verso Books, 19 May 2020, at www.versobooks.com/lists/4384decolonization-and-anti-racism.
}

Cite this article: Byrd BR (2023). Writing the World at the End of Empire. Modern Intellectual History 20, 345-355. https://doi.org/10.1017/S1479244321000640 